Metaphor, Creativity, and Technical Writing Author(s): Jerome Bump

Source: College Composition and Communication, Vol. 36, No. 4 (Dec., 1985), pp. 444-453 Published by: National Council of Teachers of English

Stable URL: http://www.jstor.org/stable/357863

Accessed: 10-08-2016 16:02 UTC

Your use of the JSTOR archive indicates your acceptance of the Terms \& Conditions of Use, available at

http://about.jstor.org/terms

JSTOR is a not-for-profit service that helps scholars, researchers, and students discover, use, and build upon a wide range of content in a trusted digital archive. We use information technology and tools to increase productivity and facilitate new forms of scholarship. For more information about JSTOR, please contact support@jstor.org.

National Council of Teachers of English is collaborating with JSTOR to digitize, preserve and extend access to College Composition and Communication 


\title{
Metaphor, Creativity, and Technical Writing
}

\author{
Jerome Bump
}

Although "metaphor" is listed in the curent Handbook of Technical Writing as a device which "often helps clarify complex theories or objects," the term is conspicuous by its absence in technical writing textbooks. ${ }^{1}$ Most authors of such books occasionally use metaphor themselves, but, except for briefly suggesting the possible use of analogy for expanding a definition or description, they do not recommend that students use metaphor. ${ }^{2}$ One of the reasons for this attitude is apparently the traditional association of metaphor with emotion, ${ }^{3}$ but the neglect of figurative language, like the exclusion of most personal pronouns, expressions of emotion, and literary techniques from technical writing also excludes many of the manifestations of the creativity that is the essence of science and engineering. In fact most of these features are evident in the writing of innovative scientists and engineers. Thus textbooks appear to ignore not only the role of creativity in science and engineering but many of the best examples of discourse in those fields as well.

This problem becomes particularly obvious to students when a technical writing textbook is assigned along with a collection of readings by great engineers or scientists. In Engineers as Writers, for example, Walter Miller and Leo Saidla ask students to comment on the use of metaphors and analogies in classics of engineering writing, along with engineers' use of first-person active voice and their expressions of emotion and of their own personalities. ${ }^{4}$ Yet technical writing textbooks pay little attention to these subjects. The contrast is even more striking in Elizabeth Bowen and Joseph Mazzeo's more recent Writing About Science. ${ }^{5}$ Essays by Gerald Holton, Richard Feynman, George and Muriel Beadle and others in their section on "Writing for Professional Audiences" demolish the myth that creativity in science consists of impassively following a rigorous step-by-step procedure and communicating the results in completely objective, perfectly plain prose. Ways of revealing emotion in this collection range from the use of exclamation marks by George

Jerome Bump is Professor of English at the University of Texas in Austin. He has published numerous articles on Victorian and other literature, and is the author of a book on Gerard Manley Hopkins. He has taught technical writing, and is currently working on a book on creativity. 
Wald (pp. 291, 295), Charles Darwin (p. 248), and Garrett Hardin (p. 337), to Holton's discussion of Kepler's "intense emotional involvement" (p. 308) and ecstatic transport (p. 320). Wald finds beauty in cartilage and muscle tissue patterns (p. 301), while Darwin expresses "unbounded astonishment" at lagoon islands (p. 236), "truly wonderful structures" (pp. 239, 245). If the myth of scientists' perfect distance and detachment is called into question by such displays of emotion, the rule of writing invariably in impersonal, impassive constructions in science is also put in doubt by the use of "I," "you," "we," and "our" throughout the collection. ${ }^{6}$

This more personal, more emotional approach to science is apparently more conducive both to metaphor and to other manifestations of the revolt against dualism which the fusing process of metaphor epitomizes, such as "both/and" thinking and interdisciplinary thought. Instead of taking literally the simplistic partition of a subject into "either" the first "or" the second of two categories, creative breakthroughs are often achieved by perceiving that in reality the subject consists of "both" the first "and" the second parts. The most famous example of the replacement of either/or by both/and thinking in our century is Einstein's rejection of the absolute dualism of matter and energy, but it is also obvious in the theory of the "complementarity" of the wave and particle models of electromagnetic fields discussed by Feynman (p. 224). The behavior of such fields can be understood fully only if they are considered, metaphorically, as both "waves" (at low frequencies) and "particles" (at high frequencies). Interdisciplinary thought is by definition another example of such both/and rather than either/or thinking. Many essays in Bowen and Mazzeo's collection reveal that sense of the permeability of boundaries between fields that permits interdisciplinary thought, a hallmark of creativity from Kepler's integration of physics and astronomy to the use of metaphors drawn from writing and information theory to convey the process of DNA replication. ${ }^{7}$

The ultimate revolt against dualism, however, the essence of creativity according to theorists from Aristotle to the present, is metaphor. Hence, although textbooks do not prepare students very well for the discovery, we should not be surprised to find metaphor and analogy playing an important role in an engineering classic, John Smeaton's account of the construction of the Eddystone Lighthouse, the foundation of technical writing in English. In the first section excerpted by Miller and Laidla, Smeaton imagines that the moorstone courses of the old lighthouse acted "like the ballast of a ship" and that the violent agitation of the waves had rounded the seat of the tower "like the Rockers of a cradle" (p. 90). Then he proceeds to more purely metaphorical thought, deciding "not to increase the size of the present building in its Waist," yet "On this occasion, the natural figure of the waist or bole of a large spreading Oak, presented itself to my imagination" (p. 91). This image dominates his attempts to imagine a lighthouse strong enough to withstand violent storms (pp. 91-92). Without such a breakthrough in design, "the 
building of the Eddystone Lighthouse with stone would be tantamount to the rolling of the stone of Sisyphus" (p. 92).

Metaphors pervade the section on "Professional Audiences" in Writing About Science as well. Perhaps the most thorough and significant demonstration of the crucial role of metaphorical thinking in science in this section is Holton's account of Kepler's heavy reliance on analogues (pp. 308, 322), models (pp. 309,316 ), and archetypes (p. 322). Kepler's recurrent use of the clock metaphor (pp. 311, 312, 315, 324) reveals the pattern of his archetypal thinking, but he was also capable of more anthropomorphic imagery, such as the image of the planets obsessed by magnetic forces (p. 324). Holton identifies metaphorical thinking in Copernicus (p. 323) and Newton (p. 308n) as well and himself makes effective use of metaphors (p. 308). Nevertheless, the most fascinating of these essays in this respect for the teacher of English is probably Hardin's essay on DNA, for he consistently compares the function of DNA to that of human communication, speaking in terms of "letters" (p. 206), punctuation (p. 202), "message" (pp. 203, 205), and "reading" (p. 203) and using a wealth of other metaphors, including some drawn from Morse code (p. 202) and tape recording (p. 202). Feynman focuses on the more traditional imagery of the "machinery" of interaction between atoms (p. 220) but uses an extended analogy of a cork in a pool of water to set up the metaphor of waves in electromagnetic fields (pp. 222-223). Similarly, Wald returns again and again to conventional images of "a living organism" as "an intricate machine" (pp. 298,300 ) and the sea as originally a "broth" of molecules (pp. 299, 301, 302), but he also compares photosynthesis to capitalism (p. 304). These authors demonstrate the importance of metaphor for communicating scientific ideas, as well as for generating original "creative" perceptions in science.

Yet they are not using metaphors naively or unscientifically. They are obviously aware of the limits as well as the powers of their metaphors. Feynman, for instance, points out that the frequency range of electromagnetic waves that put radio broadcasts "on the air" actually "has nothing to do with the air! We can have radio broadcasts without any air" (p. 223). More importantly, as we have seen, he points out the limits of the wave metaphor itself, and the need to replace it with the particle metaphor at higher frequencies (p. 224).

The limitations scientists most often erect, however, surround that class of metaphors we call personification, comparisons of the subject to some aspect of ourselves. Our tendency to personify is indeed one of the most important sources of the scientific opposition to metaphor, for it suggests the introduction of personal bias and emotion into science. Scientific suspicion of this kind of anthropocentrism is apparent in Wald's critique of "mythical accounts of a supernatural creation of life" (p. 288), in Julian Huxley's response to the charge that the idea of progress is "a mere anthropomorphism" (p. 261), and in Hardin's criticism of Adam Smith's metaphor of the operation of the "invisible hand" in economic affairs (p. 335).

Yet for these writers the fact that others have abused anthropocentric meta- 
phors is no reason to throw them out altogether. For instance, Hardin himself talks of bonds at the ends of purine or pyrimidine bases that are "unsatisfied" " (p. 211) and methods of replication which involve "'daugher" molecules (p. 213). Similarly, despite his awareness of the limits of such metaphors as "on the air" and electromagnetic "waves" and "particles," Feynman does not hesitate to suggest that when atoms "come close together, they can 'see inside' each other and rearrange their charges" (p. 220) or that a positive charge "feels a force" in the presence of a negative charge (p. 222).

This kind of personification is even more important in creative scientific thinking than it is in scientific discourse. W. J. J. Gordon calls it "personal analogy" and focuses on "Dr. Rich, the great General Electric scientist," who is able "to think like an electron . . . or imagine himself a light beam whose reflection is being measured," and on such predecessors as Einstein, Kekule, and Faraday:

Personification and anthropomorphization ... "How would it feel if it were human and could feel?" "How would I feel if I were it?" . . . the chemist may personally identify with the molecules in action. Faraday "looked ... . into the heart of the electrolyte endeavoring to render the play of its atom visible to his mental eyes." The creative technical person can think himself to be a dancing molecule, discarding the detachment of the expert and throwing himself into the activity of the elements involved. He becomes one of the molecules. He permits himself to be pushed and pulled by the molecular forces. He remains a human being but acts as though he were a molecule. For the moment the rigid formulae don't govern, and he feels what happens to a molecule. Einstein recognized the role of empathic personal identification. . . . Kekule, by identifying himself with a snake swallowing its tail, developed an insight into the benzene molecule in terms of a ring rather than a chain of carbon atoms. ${ }^{8}$

As I have suggested elsewhere, ${ }^{9}$ the apparent resistance of science to the ancient tradition of personification in religion and the humanities is simplistic, for metaphor is one of the scientist's as well as one of the poet's most powerful tools.

Max Black demonstrated that metaphorical models are in fact indispensable tools for the generation of creative hypotheses and effective explanations in science. He has shown that the "use of a 'subsidiary subject' to foster insight into a 'principal subject" " through metaphor "is a distinctive intellectual operation ... demanding simultaneous awareness of both subjects but not reducible to any comparison between the two." 10 Metaphors enable us to make new connections and see things in a new way: "The extended meanings that result, the relations between initially disparate realms created, can neither be antecedently predicted nor subsequently paraphrased in prose. . . . Metaphorical thought is a distinctive mode of achieving insight, not to be construed as an ornamental substitute for plain thought" (pp. 236-237).

As Clerk Maxwell's account of the discovery of the similarity between an 
electrical field and an incompressible fluid suggests, the truly innovative scientist often discovers that his subjects must not be regarded as mere mathematical abstractions, and he moves rapidly from the as if of analogy to the as being of metaphor, making increasingly ontological commitments to a theoretical model, a sustained and systematic metaphor. "In as if thinking there is a willing suspension of ontological unbelief, and the price paid, as Maxwell insists, is absence of explanatory power" (p. 228). Black demonstrates, moreover, that Maxwell's version of metaphorical thinking is "characteristic of the practice of the great theorists in physics. Whether we consider Kelvin's 'rude mechanical models,' Rutherford's solar system, or Bohr's model of the atom, ... it is often hard to conceive how the research in question could have been brought to fruition without recourse to the model" (pp. 228-229, 233).

We need a more sophisticated approach to the role of metaphor in technical writing for an understanding not only of the leading edge of research, represented by the discoveries of scientists like Bohr, Rutherford, Kelvin, and Maxwell, but also of the history and the most basic assumptions of science. For example, Holton points out how, "using his characteristic method of reasoning on the basis of archetypes, Kepler piles further consequences and analogies on his arguments. . . . 'It is because he sees the sun and planets against the background of this fundamental image (archetypische Bild) that he believes in the heliocentric system"' (pp. 322-324). One of Kepler's basic modes of thought was what in science is often called thinking in terms of analogue models. In the humanities, we call it thinking in terms of extended analogies or metaphors. Kepler started with a basic, fundamental analogy (for Holton an "archetype" or "fundamental image"), such as a comparison of the worldsphere with the Trinity, and then extended the analogy further and further.

For us as for Kepler such fundamental analogies determine much of what we will discover. Thus, in order to conceive of a truly revolutionary change such as Einstein's, we need first to become conscious of those most basic metaphors of the universe which we simply take for granted. Einstein first had to perceive that the "aether-drift" was the wrong metaphor, and Feynman must begin his essay on modern physics: "Before 1920, our world picture was something like this: The 'stage' on which the universe goes is the three-dimensional space of geometry, as described by Euclid, and things change in a medium called time" (p. 219). The power of such basic metaphors is suggested by Hardin: "on a verbal level, we can only speak of what the poet Goethe called the Zeitgeist-the spirit of the times. 'We see only what we know,'said Goethe" (p. 200).

Our need for more consciousness of the role of metaphors and models in technical writing may be illustrated by supplementary texts other than Writing About Science, moreover. In addition to Engineers as Writers, James Watson's The Double Helix, for instance, "brings home to the nonscientist," as Jacob Bronowski put it, "how the scientific method really works: that we invent a model and then test its consequences, and that it is this conjunction of imag- 
ination and realism that constitutes the inductive method. The models in science are not always as concrete as those which Crick and Watson put together with their hands; Albert Einstein could not have made a visible model of his space-time" (p. 203). What Einstein made would more properly be called a metaphor, as Robert Frost pointed out, citing Einstein's "In the neighborhood of matter space is something like curved," emphasizing Einstein's phrase, "something like." Frost also pointed out that even mathematics is based on a metaphor ("Pythagoras' comparison of the universe with number"), as are mechanistic models of the world ("the universe as machine"), Einstein's famous equation, " $\mathrm{E}=\mathrm{MC}^{2}$ " ("A thing, they say, is an event"), and the theory of evolution ("the metaphor of the growing plant"). ${ }^{11}$

The evolutionary metaphor is identified primarily with Darwin, of course, whose work became a paradigm of the life sciences, an accepted example of scientific practice which inspired a coherent tradition of research. Yet Darwin's essay on corals in the Bowen and Mazzeo collection illustrates conspicuously most of the features which the textbooks argue should be de-emphasized in technical writing: the use of "I," revelations of emotion, poetic sound effects, and metaphor, including personification of the corals as "little architects" (p. 244). Moreover, when we turn from this essay to perhaps the best supplementary texts of all, The Origin of Species and The Descent of Man, the role of metaphor becomes still more conspicuous. As the conclusion of Chapter IV on Natural Selection in the Origin of Species reveals, Darwin, like Smeaton, found the tree to be a very important image. Throughout his text his conciousness of the role of metaphor is obvious:

I should premise that I use this term [struggle for existence] in a large and metaphorical sense including the dependence of one being on another. ... Others have objected that the term selection implies conscious choice in the animals which become modified; and it had even been urged that, as plants have no volition, natural selection is not applicable to them! In the literal sense of the word, no doubt, natural selection is a false term; but who ever objected to chemists speaking of the elective affinities of the various elements? - and yet an acid cannot strictly be said to elect the base with which it in preference combines. It has been said that I speak of natural selection as an active power or Deity; but who objects to an author speaking of the attraction of gravity as ruling the movements of the planets? Everyone knows what is meant and is implied by such metaphorical expressions; and they are almost necessary for brevity. So again it is difficult to avoid personifying the word Nature. . . . It may metaphorically be said that natural selection is daily and hourly scrutinizing, throughout the world, the slightest variations; rejecting those that are bad, preserving and adding up all those that are good; silently and insensibly working . . . ${ }^{12}$

As we follow the workings of the mind of Darwin or Smeaton we cannot escape the fact that metaphors, even personifications, can be very important techniques in the invention and discourse of great engineers and scientists. Thus it would seem that if we want our students to become potentially great 
scientists, inventors, and engineers, we need to familiarize them with the role of metaphor in scientific creativity. A command of metaphor should help them see the limits of the world-pictures and models of their predecessors, be more at ease with ambiguity and paradox, and stretch their imaginations in many ways. Mastery of metaphor will help them see old things in new ways, connect objects and ideas which seem disparate, and thus generate more insights, more fruitful hypotheses, and more comprehensive and effective models.

A habit of metaphorical thinking will thus add to their chances of inventing a great engineering design like Smeaton's, or making a great scientific breakthrough like Kepler's. Familiarity with metaphor will also help them develop their capacities for transcending simplistic dualisms of all kinds, that is, for engaging in both/and thinking, for integrating the abstract and the concrete, and for making interdisciplinary syntheses, all characteristics of many creative minds in science and engineering. In short, they would be well advised to imitate the reliance on metaphor that Maxwell revealed in one of his letters: "I do not know the Game laws and Patent laws of science . . . but I certainly intend to poach among your electrical images." 13

Acquaintance with and skill in the use of metaphor will also help students communicate their discoveries better by enabling them to clarify "complex theories or objects," as the Handbook of Technical Writing recommends. In addition, it will help them acquire a sense of the metaphorical implications of the terms they have chosen, as Darwin and Huxley did, and develop more effective explantions, as did Maxwell, Kelvin, Rutherford, Bohr, and the authors collected in such anthologies as Engineers as Writers and Writing About Science.

One place to introduce students to the habit of metaphorical thinking would be in technical writing textbooks. A section on the heuristics of discovery, like those now appearing in regular and cross-disciplinary rhetoric textbooks, might be added to such texts; the new section might explore metaphorical thinking. For example, one recent college rhetoric revives the common places of invention-in which metaphorical thinking could be a development of comparison and contrast-and the special places of invention, in which metaphorical thinking is a natural extension of thinking analogically. ${ }^{14}$ This particular text also includes a unit on thinking in terms of our "models of the world" and one on interdisciplinary thought which, as we have seen, can be related directly to mastery of metaphor. ${ }^{15}$

Initial sections on "getting started" in college rhetorics, especially when they include brainstorming, problem-solving, journal writing, and other forms of private, exploratory, and discovery writing, ${ }^{16}$ might also be modified to encompass technical writing. The connection between metaphor and brainstorming is apparent in the title of a section in the chapter on heuristics in a new cross-disciplinary rhetoric: "Word associations, analogy, metaphor." 17 Unfortunately, this section is only two brief paragraphs, though it is followed 
by another short section titled "seeing a topic as a particle, wave, or field," 18 all metaphorical lenses drawn from the field of physics.

Of course, the introduction of metaphorical thinking into technical writing courses need not wait upon changes in textbooks. Student awareness of the presence and importance of metaphors can be heightened in class discussion and examination of the metaphors in supplementary texts such as Writing About Science and The Origin of Species. Exercises on metaphor in sections on diction in almost any college rhetoric may be extracted and developed into more extensive calisthenics of the metaphorical imagination. ${ }^{19}$ One of the most fruitful techniques remains the student journal, which can easily be converted into a means for developing the habit of metaphorical thinking and other kinds of exploratory writing in science and engineering. The journals of many creative writers provide instructive examples of such "treasuries" of innovative metaphors, ${ }^{20}$ and students can start keeping their own journals to develop expertise in metaphor.

A more dramatic classroom technique which demonstrates how metaphorical thinking can help solve practical problems is brainstorming. To give students an idea of how metaphors can initiate breakthroughs in problem solving, examples from history can be cited; Isambard Brunel, for instance, by watching a shipworm burrow into wood, was able, by analogy, to design the cassion method of underwater construction, and by studying the membrane of the human ear Alexander Graham Bell was able to invent an analogous membrane for the telephone. Then, to see how this kind of thinking is encouraged by brainstorming, students can consult the records of Gordon's brainstorming sessions in industry. For example, in order to invent "a new and practical constant speed mechanism" to control a shaft revolving at various speeds "each member of the group metaphorically entered" the mechanism (p. 38). Or, "faced with the problem of inventing a dispenser which could be used with various products from glue to nail polish" they conceived of the device, metaphorically, as a clam, a human mouth, a horse's anus, etc. (pp. 45-47). With such brainstorming models before them, students might well become enthusiastic about classes devoted to similar exercises.

There may even be an occasion or two in a technical writing course to indulge in that "education by poetry" which Frost felt was the best way to teach not only the powers and limits of metaphors but the essence of thinking itself. ${ }^{21}$ On such occasions the technical writing course itself may demonstrate that sense of the permeability of boundaries which is such a prominent feature of creativity in science and engineering, as in so many other fields.

\section{Notes}

1. Charles T. Brusaw, Gerald J. Alred, and Walter E. Oliu, Handbook of Technical Writing, 2nd. ed. (New York: St. Martin's Press, 1982), p. 374; I have yet to find the term "metaphor" in the index of a single technical writing textbook. The term does appear in textbooks designed 
for writing across disciplines, of course, but the page numbers cited are not in the scientific writing section. See, for example, Elaine P. Maimon et al, Writing in the Arts and Sciences (Cambridge, MA: Winthrop Publishing Company, 1981). By technical writing I mean "exposition about scientific subjects and about various technical subjects associated with the sciences," as Gordon H. Mills and John Walter put it in Technical Writing, 4th ed. (New York: Holt, Rinehart, and Winston, 1978), p. 4. Mills and Walter include engineering in the latter category. Many definitions are even broader, and some critics, such as Brusaw et al, do not even attempt to define the term. However, a few suggest that we might try to distinguish between "scientific" and "technical" writing; see, for instance, Carolyn Miller, "A Humanistic Rationale for Technical Writing," College English, 40, (February, 1979), 617. Admittedly, there are differences between the scientific and engineering communities, but my concern here, like hers throughout the rest of her article, is with the similarities.

2. For example, Mills and Walter use effective analogies themselves (pp. 217, 251) but only recommend that students use analogy in description of a mechanism (pp. 110-111). For similar recommendations see Deborah C. Andrews and Margaret D. Blickle, Technical Writing: Principles and Forms, 2nd. ed. (New York: Macmillan, 1982), pp. 135-136; Stephen F. Pauley, Technical Report Writing Today, 2nd ed. (Boston: Houghton Mifflin, 1979), pp. 18-19; and John M. Lannon, Technical Writing, 2nd ed. (Boston: Little, Brown, 1982), pp. 96, 160. Lannon avoids the term "analogy" as well as the term "metaphor."

3. The association of metaphor with emotion and with persuasive rather than more objective writing can be traced at least as far back as Longinus's On the Sublime. In his chapter on metaphor (ch. 32), he associates metaphor with strong emotion, but it is significant that he goes on to recommend metaphor in description as well, choosing as his example what we would now call technical writing: the anatomical description of the human body. See T. S. Dorsch, ed., Classical Literary Criticism: Aristotle, Horace, Longinus (New York: Penguin Books, 1965), pp. 140-142.

4. Walter Miller and Leo Saidla, Engineers as Writers (New York: Van Nostrand, 1953). They ask students to comment on metaphor on pp. 24, 63, 296, 333; on analogies, pp. 232, 333; on first-person active voice, pp. 85, 114; on expression of emotion, p. 253; and on expression of personality, pp. 102, 114, 232, 333-page numbers hereafter cited in the text.

5. Mary Elizabeth Bowen and Joseph A. Mazzeo, ed., Writing About Science (New York: Oxford Univ. Press, 1979)-page numbers hereafter cited in the text.

6. See, for example, pp. 220, 221, 236, 246, 251, 274-275, 305. Another good supplementary text for scientific and technical writing courses illustrates the use of personal pronouns: Albert Einstein, Relativity, The Special and General Theory, trans. Robert W. Lawson (New York: Crown, 1961). See especially pp. 1, 23, 79, 83, 111.

7. Pp. 317, 201-206. See also James Watson, The Double Helix, A Personal Account of the Discovery of DNA, ed. Gunther S. Stent (New York: W. W. Norton, 1980)-page numbers hereafter cited in the text. Interdisciplinary thought is evident throughout this text, from Stent's introduction to Crick's discussion of the integration of $\mathrm{x}$-ray crystallography and molecular biology, to Alex Comfort's review, "Two Cultures No More," to our realization that Watson's book itself is an important interaction between the fields of literature and science.

8. W. J. J. Gordon, Synectics, The Development of Creative Capacity (New York: Harper and Row, 1961), pp. 31, 37-38-pages cited hereafter in the text.

9. Jerome Bump, "Stevens and Lawrence: The Poetry of Nature and the Spirit of the Age," Southern Review, 18 (Winter, 1982), 50-51.

10. Max Black, Models and Metaphors (Ithaca, NY: Cornell Univ. Press, 1962), p. 46-page numbers hereafter cited in the text.

11. Robert Frost, "Education by Poetry: A Meditative Monologue," in Arthur M. Eastman et al, ed., The Norton Reader, 4th ed. (New York: W. W. Norton, 1977), pp. 410-412.

12. Philip Appleman, ed., Darwin (New York: W. W. Norton, 1970), pp. 154, 116, 121, 123 - another useful supplemental text in scientific and technical writing courses.

13. Cited by Robert K. Merton, "Making it Scientifically," in Watson, p. 215.

14. Patrick Hartwell and Robert Bentley, Open to Language (New York: Oxford University Press, 1982), pp. 545-548, 572-575.

15. Hartwell, pp. 566-572. 

$20-23$.

16. Journals and brainstorming are discussed in Hartwell, pp. 7-10, and in Maimon, pp.

17. Maimon, p. 27; however, the authors recommend that students "avoid metaphor in philosophy papers" (p. 201), and the term does not even appear in the scientific writing section.

18. Maimon, p. 28.

19. See, for example, Hartwell, pp. 306-307, 309-310; Maimon, pp. 47-48.

20. See, for instance, E. D. H. Johnson, ed., The Poetry of Earth (New York: Atheneum, 1966).

21. See note 11. For an example of a discussion of a poem as a metaphorical model of the universe see the account of Hopkins' "Pied Beauty" in Jerome Bump, "Hopkins, the Humanities, and the Environment," The Georgia Review, 20 (Spring, 1974), 227-244. For an example of a discussion of literary prose as a calisthenics of metaphor for scientists and engineers, see the citations of Thoreau's Natural History of Massacbusetts in Gordon, p. 110.

\section{Results of 1985 Election}

The following candidates were elected to office in the balloting that ended on 1 October. They will take office thirty days after the election results are officially announced at the CCCC/College Section Luncheon on Saturday 23 November in Philadelphia.

\section{Assistant Chair:}

Secretary:

(two-year term)

Executive Committee:

(three-year term)

Nominating Committee:

(one-year term)

\author{
David Bartholomae \\ Erika Lindemann \\ James L. Kinneavy \\ Donald M. Murray \\ Deborah H. Holdstein \\ T. Clifford Bibb \\ Judith R. Lambert \\ Robert J. Connors \\ Linda H. Peterson \\ Dawn Rodrigues
}

\section{Announcement and Call for Papers: Penn State Conference on Rhetoric and Composition}

Edward P. J. Corbett will be the Keynote Speaker at the fifth annual Penn State Conference on Rhetoric and Composition, to be held 8-11 July 1986, at State College, Pennsylvania. The consultants will be James Berlin, John Gage, Dixie Goswami, Maxine Hairston, and Geneva Smitherman. Those interested in participating are invited to present papers, demonstrations, or workshops. One-page proposals will be accepted through 15 April. If you wish to submit a proposal or volunteer to chair a session, or if you are interested in more information about attending or participating in the conference, write to Professor Marie J. Secor, Department of English, The Pennsylvania State University, University Park, PA 16802. 